individual cases, memory under-performance is neither consistent nor persistent, but it is twice as frequent as among controls.

The recognition of these memory impairments should prompt academic accommodations and a more structured classroom environment. Previous investigators have reported that ongoing seizures may impair school performance and memory and learning. Memory deficits and underachievement may be transient (Deonna et al. 2000), or persistent (Austin et al. 1999).

\title{
EPILEPSY AND FRAGILE X SYNDROME
}

The seizure history of 136 patients with fragile X syndrome (FXS), (age range 2 to 51 years; 113 males and 23 females), were reviewed at RUSH-Presbyterian-St Luke's Medical Center, Chicago, IL. Seizures occurred in $13.3 \%$ of males with FXS and $4.3 \%$ of females; and the majority were partial seizures. Epileptiform EEGs were found in $77 \%$ individuals with seizures and $23 \%$ of those without, most commonly centrotemporal spikes. Seizures were easily controlled in 14 of 16 treated. Benign rolandic epilepsy was the most common epilepsy syndrome in FXS patients, all of whom showed remission. A specific relation between absence of fragile $\mathrm{X}$ mental retardation protein and benign rolandic epilepsy with centrotemporal spikes is suggested. (Berry-Kravis E. Epilepsy in fragile X syndrome. Dev Med Child Neurol Nov 2002;44:724-728). (Respond: Elizabeth Berry-Kravis MD PhD, Department of Pediatrics, Neurology, and Biochemistry, RUSHPresbyterian-St Luke's Medical Center, 1725 West Harrison, Suite 718, Chicago, IL 60612).

COMMENT. Complex partial seizures are the most common seizure type and benign rolandic epilepsy with centrotemporal spikes in the EEG the most common epilepsy syndrome in patients with fragile X syndrome. Seizures in FXS are easily controlled with anticonvulsants and are usually limited to childhood. Seizures are less frequent in girls with FXS than in boys, attesting to the milder phenotypic manifestations of FXS in girls.

Fragile $\mathrm{X}$ carrier state may underlie a diagnosis of essential tremor in older male patients, according to a report of 2 fragile X carriers (ages 68 and 63 years) seen at the University of Colorad), Denver, and University of Toronto, Ontario (Leekey MA, Munhoz RP, Lang AE et al. Arch Neurol January 2003;60:117-121). In addition to a disabling intention tremor, the patients had impaired tandem gait, generalized brain atrophy with frontal psychological deficits, and T2 middle cerebellar hyperintensities on MRI. Both had elevated FXMR gene 1 messenger RNA and reduced FXMR 1 protein.

\section{GENETICS OF ABSENCE EPILEPSY AND FEBRILE SEIZURES}

In a large family with epilepsy studied at the University of Melbourne, Australia, FS in 18 children were inherited as autosomal dominant with $75 \%$ penetrance (GABA receptor subunit mutation on chromosome 5), and absence epilepsy in 8 required the GABA gene on chromosome 5 interacting with a possible further gene on chromosomes 10, 13, 14 and 15. (Marini C, Harkin LA, Wallace RH et al. Brain Jan 2003;126:230-240). 